\title{
Inhabiting a vulnerable and wounded earth: restoring response-ability
}

\author{
Brunilda Pali and Ivo Aertsen*
}

In 'our separate kinds of expertise and experience, we know both too much and too little' writes multispecies feminist theorist Donna Haraway in Staying with the trouble (2016: 4), calling for boundary crossing transdisciplinary work and alliances that will take us both beyond naïve hope or defeatist despair when thinking about our life in a 'vulnerable and a wounded earth' (Haraway, 2016: 10). Haraway says she is not 'interested in reconciliation or restoration' but 'deeply committed to the more modest possibilities of partial recuperation and getting on together. Call that staying with the trouble' (Haraway, 2016: 10). So, let us stay with the trouble!

In staying with the trouble, scholarship requires 'passion and action, holding still and moving, anchoring and launching' (Haraway, 2016: 10). Among different boundaries we have crossed and intersections we have anchored and launched together in our engagement with what we have always seen as a dynamic and living restorative justice movement, the environmental one is by far one of the most challenging and exciting ones. In spring 2019, we brought together in an exploratory seminar in Leuven an interdisciplinary, intergenerational and international group of people who were as excited about these new possibilities as we were (see Pali, 2019). John Braithwaite opened the seminar by calling for the mobilisation of the restorative power and the restorative imagination of humankind in service of life on earth (see Braithwaite, Forsyth \& Cleland, 2019: 9). Since then, a lot has happened: ideas have been shared, threads have been made, networks have been formed and as this special issue of The International Journal of Restorative Justice will show, written works have been created and are ready to be shared with the restorative justice community.

* Brunilda Pali is a Senior Researcher at the Leuven Institute of Criminology, KU Leuven, Belgium, and a Lecturer at the Department of Political Sciences, University of Amsterdam, the Netherlands. Ivo Aertsen is Emeritus Professor of Criminology, Leuven Institute of Criminology, KU Leuven, Belgium.

Contact author: Brunilda.pali@kuleuven.be. 


\section{Why this engagement now, and what gifts does restorative justice bring?}

As Braithwaite et al. (2019: 8) write:

climate change, species loss, growing and urbanising populations, diffuse sources of pollution and predatory capitalism are all placing increased pressures on our natural and built environment, often leaving the most marginalised communities to bear the worst of the burden of environmental pollution.

Clearly at this moment in time, anthropogenic forces significantly threaten ecological stability and sustainability as we cross planetary ecological boundaries, and the ecological decline has 'widespread justice implications for human, nonhuman animals and for the living ecosystem itself' (Lynch, Long \& Stretesky, 2019: 24).

In the last decades, quite a lot of energy has been spent on drafting and adopting declarations, agreements, treaties, laws and regulations, and certainly substantial progress has been made on improving the technical side of environmental protection and regulation (Langer, 1994). But improving the technical and regulatory side is clearly not enough. What is needed at this stage is what Italian peace- and eco-activist and intellectual Alexander Langer has called a real 'ecological conversion', a change of direction required to ensure the continuing habitability of our planet and coexistence between its living creatures (Langer, 1994). This conversion needs to be personal and collective, and needs to become a desirable sociocultural project, if the environmental agenda is not to remain piecemeal and unconvincing. As climate and environmental justice activism, in general, and more recently, as worldwide youth protests for the climate have showed, we might have reached a new stage of a wide, cultural and social environmental consciousness. Other developments that testify to this have been the broadly endorsed movement for the ecocide law, the rights of nature movement, citizen-led environmental and climate change litigation cases and the creation of commissions for the rights of future generations (see Wijdekop, 2019a).

Yet, despite both the incremental improvements on the regulatory and protection side, and the 'ecological conversion' taking place at the level of the collective consciousness, we are yet to develop meaningful accountability, justice and repair in cases of environmental harms, conflicts and crimes. According to the late Scottish corporate barrister Polly Higgins, who drafted the ecocide law and launched the 'Stop Ecocide' campaign, we are very different from other species in that we have the capacity to recognise and understand the consequences of our actions and take collective action to remedy them (Higgins, 2010). And yet, no other species is destructive at the scale that we are. We are deeply entangled in creating environmental harms, even though the harms do not affect each of us in the same way. We are also entangled through life standards, benefits, safety, silence, apathy, indifference and distance in creating environmental harm. So, Higgins' main concern was on how we take 
responsibility for the way we engage with our ecosystems (Higgins, 2017). Given the daunting tasks that lie ahead, we need to think of the notion of taking responsibility in this context as Haraway (2016) suggests: finding ways to restore response-ability, our ability to respond as we stay with the trouble.

The environmental work is situated at the intersection of a multitude of ideas and aspirations that revolve around law, justice, rights, care, restoration, activism and regulation. Given its position between the justice system and society (Aertsen, 2006, 2008), restorative justice might be uniquely placed and able to bridge the gap between different worldviews, frameworks and perspectives. And even though restorative justice today is still a strongly anthropocentric approach, thanks to its underlying relational philosophy (Llewellyn \& Morrison, 2018), it has the potential, more than any other justice approach, to incorporate ecocentric perspectives, indigenous justice approaches and perspectives from the rights of nature movement. What represents the radical potential of a restorative engagement with the environmental area, writes Varona (this issue), is its understanding and value of life as interdependent, global and intergenerational, beyond anthropocentrism'.

Starting the search for justice not based on the question of which laws have been broken but focusing on who and what has been harmed, who is accountable to repair and how to repair that harm, makes restorative justice particularly interesting in the environmental area, where there is extremely low reporting, prosecution and sentencing (Minguet, this issue). Depending on the nature and effects of the environmental crime, victims can be individuals and their families whose life, health, property and living conditions are impacted, as well as neighbourhoods and larger communities, the physical environment, future generations and the other-than-human life. Other stakeholders can be corporations (managers, shareholders, employees), states, public bodies and civil society organisations. In environmental crime, recognising the broader societal dimension is crucial indeed, since harms can be caused to communal natural resources, public infrastructure and heritage. The most valuable contribution restorative justice makes to environmental conflicts is creating safe spaces for all stakeholders to exchange different views and hold difficult conversations around what has happened and what must happen in the future to ensure accountability and repair (see Forsyth et al., this issue; Hamilton, this issue; Varona, this issue).

Having those conversations has to be conceived as knowledge sharing (see Wilson, 2016). There is, for example, a deep and fundamental disconnect between the nonindigenous and indigenous meaning and use of land and environment, and the conception of the world and nature in general. What is a natural resource to be exploited by some in the interest of humankind, can be a sacred land for others. This is why harm to those environments and lands often affects not only the health and prosperity of indigenous peoples but also their sense of belonging, communal identity and integrity (see Hamilton, this issue; Minguet, this issue). For the Mãori, writes Hamilton (this issue), the environment is them. Such conflicts 'may arise from denial of the very existence of sacredness in the land, or it may result from mutual competition for the same land' (Podziba, 2018: 384). 
At the very heart of all this lies in fact the need for an urgent epistemic dialogue and cohabitation.

The dialogic element of environmental restorative justice reduces social distance and domination in an area where distance and domination are enormous, and often the cause of the harm. When engaging in this area, we enter into a world of systemic injustices, extreme power imbalances and high victim vulnerability (Aertsen, 2018). We are often told in restorative justice to avoid bringing together people when there are power imbalances. But how will that power difference be corrected or that gap closed if we do not engage in some form of power sharing? Not through activities that make the victim more vulnerable and further empower the offender, but those that make the offender more vulnerable and empower the victim. Restorative justice processes have to be conceived, therefore, also as distance-reducing and power-sharing mechanisms. Often, affected communities are silenced and left out of important decisions that regard them, while restorative justice's democratising elements of voice and participation are in line with the communities' and public's right to participate in decision-making, access to information and access to justice.

Finally, the environmental restorative justice perspective is driven essentially by the principles of harm reparation, restoration and healing, and in that it is deeply aligned with the environmental restoration movement (see Besthorn, $2004,2012)$. In cases of environmental harm, simply punishing the perpetrator of the pollution or destruction of natural resources is meaningless if there is no repair of the damage done and if there is no assurance that this type of behaviour will not happen again. As a result of restorative processes, a plan of action or a restorative contract which contains suggestions to prevent or repair harms and damages can be drawn.

\section{Experiences of restorative justice in environmental regulation, prosecution and restoration}

Essentially, a restorative ethos and praxis to environmental harms calls attention a) to the necessity to repair the harms that have been done to the environment, to its human and other-than-human inhabitants and to communities, their infrastructure and future generations, and b) to build different relational and ethical systems that prevent future harm. Many have started recognising the value and potential of restorative responses to environmental harms, crimes and conflicts. Already in the 1980s, 'environmental mediation' was explored (Amy, 1983). Higgins (2010) came up with the idea of using restorative justice as part of the sentencing process for ecocide convictions. In 2011, her draft Ecocide Act was tested in the UK Supreme Court in a mock trial, where a few mediators were involved (see Kershen, 2019; Rivers, 2012). Inspired by these trials, in 2019 environmental artist Maria Lucia Cruz Correia created an art-based intervention of a restorative court unit called the Voice of nature: the trial. In this work, the artist designed a participatory and immersive experience of a restorative court intervention where several elements were experimented with, such as victims' 
testimonies, intervention by legal and other experts, ways to listen to the voice of nature, commitment to become 'guardians of nature' and drafting of restorative contracts (see Notes from the Field, Correia, this issue).

Exciting and interesting alignments have been made between restorative justice and the movement to recognise ecocide and related initiatives to acknowledge the rights of nature and the duty of care for the environment. Essentially in her writings and her work, following Higgins, Wijdekop (2019a) sees the commodification of nature at the heart of the problem, arguing that we need to move collectively from a right to exploit to a duty of care, first at the level of consciousness and eventually by translating these new insights into binding laws and ethics. The rights of nature movement takes both anthropocentric and eco-centric perspectives seriously. While anthropocentric perspectives focus on the harm that is caused to humans as a result of environmental harms, an ecocentric perspective maintains that nature should be defended not only because it would affect us if it was harmed, but also because it has its own right to exist and be preserved. Rivers, mountains, forests and glaciers in New Zealand, Colombia, Ecuador, India have been recognised by national courts and legislatures as living entities with their own legal rights and legal personhood. At the same time, emerging jurisprudence has also started recognising the rights of future generations to be represented in judicial proceedings.

But the court experience with restorative justice for environmental offending does not only relate to the exploratory and artistic performative level. The most advanced experience in real courts comes from Australia and New Zealand (see Al-Alosi \& Hamilton, 2019; Hamilton, this issue). Specialist environment courts in both Australia and New Zealand have experimented with restorative justice conferences and sentencing, and restorative justice has even been included in environmental protection legislation (Forsyth et al., this issue). In the context of environmental offending, restorative justice conferences have been used both as an alternative to prosecution and at the pre-sentencing level, where the results of the conference have been taken into account during sentencing. At the same time, a variety of restorative-oriented orders have also been imposed by courts without having gone through a restorative justice process (Al-Alosi \& Hamilton, 2019).

For those who will wonder how to reconcile a restorative justice ethos in a more punitive context, White (2017; see also Conversations, this issue) argues that the repairing of harm which is sanctioned through court orders and not through voluntary and deliberative restorative justice processes is sometimes necessary in cases of corporate offending and should perhaps be called 'reparative justice' instead of restorative justice. White bases this model of 'reparative justice' on the problem-solving jurisprudence of the New South Wales Land and Environment Court (Australia), where sanctions and orders are issued to corporations creatively on an ad hoc basis, combining punitive and reparative elements.

The work of many practitioners in the field of criminal justice - judges, lawyers and mediators - who have reflected on their practices and motivations for engaging in restorative justice in such cases, is valuable (see Boyd, 2008; 
Clapshaw, 2009; Fowler, 2016; Jenkins, 2018; McElrea, 2016; Pain, Pepper, McCreath \& Zorzetto, 2016; Preston, 2011; Sugrue, 2015). We highlight here in particular the paper by Judge Brian Preston, chief judge of the Land and Environment Court of New South Wales, written in 2011, since it has laid down some of the basic conditions for implementing restorative processes in environmental offending cases. More recently, in 2016, judges of the Land and Environment Court of New South Wales, Nicola Pain and Rachel Pepper, with others, wrote a paper comparing legislation and jurisprudence in New Zealand and the Australian States of Victoria and New South Wales - three jurisdictions where restorative justice for environmental crime is possible as part of a sentencing process or separate from the criminal justice system - to conclude that the New Zealand framework was the most comprehensive one. For the United States, Aiden Stark (2016) has made a thorough analysis of the potential benefits of applying restorative justice in environmental prosecution and regulation. This paper is a good example to follow as a basis for national legislative initiative.

Another interesting experience worth mentioning in this field is the work of Dominic Barter, an international leader of restorative circles, with the RENOVA Foundation in Brazil. The RENOVA Foundation was set up by the federal government in cooperation with Samarco Mining and other companies, the owners of the tailings dam which collapsed in 2015 and caused an environmental disaster in the state of Minas Gerais (see also Da Silva, this issue). The companies signed an agreement - the so-called Transaction Term and Adjustment of Conduct (TTAC) - with federal and state prosecutors, which was ratified by federal courts in March 2016. The TTAC agreement defined 42 programmes and created the RENOVA Foundation to manage the revitalisation projects that were to take place along the Doce river and its tributaries. The Foundation coordinates efforts undertaken by more than 70 public and private entities, including the federal, state and municipal governments, the mining companies, about 30 research institutions and an even larger number of civil society organisations. The work of RENOVA, supported by Dominic Barter, has included the design of specific restorative interventions for identifying needs and creating processes so that these needs can be met, but also the creation of spaces for mourning and responding to the multiple conflicts that were arising in the local communities. An important part of the work has been embedding dialogical processes as a meta-principle throughout all that is done, from the level of the executive council right to the level of the communities that were highly affected by the death of the river (see interview of Dominic Barter by Femke Wijdekop (2019b)).

When speaking about environmental restorative justice, we enter naturally into the world of corporations and white-collar crime. Unquestionably at this intersection, the work of John Braithwaite (2002), a pioneering advocate of restorative justice, in general, and of its application to corporate crime, in particular, is valuable, especially given the links he has made between restorative justice, responsive regulation and reintegrative shaming. Other scholars have specifically addressed the dilemmas, possibilities and limits of the ways restorative justice can be applicable to corporate crime or white-collar crime (see 
Aertsen, 2018; Chiste, 2008; Gabbay, 2007; Löschnig-Gespandl, 2003; Luedtke, 2014; Umbreit, Geske \& Lewis, 2015; Walters \& Westerhuis, 2013; Wright, 2019). The literature is essentially soberly optimistic, which we think is the right attitude for restorative justice's engagement in the environmental field. Perhaps something like a Gramscian motto for pessimism of the intellect, but optimism of the will is also suitable here. Generally, a form of social, political or judicial pressure will be necessary to get something in motion at the case level. But we also assume that most corporations have good reasons to maintain public trust, reputation and right relations with their consumers and with their communities (Chiste, 2008). Such motivation of self-interest (Walgrave, 2008), together with an emerging socio-ethical awareness and a new understanding of 'corporate responsibility', might bring the big players to the table. A combination of intrinsic and extrinsic motivations might work. But we should also be very alert. Corporates might be genuine in their intentions, but often they will be cynical and market-driven, so things like automated apologies, greenwashing, mitigation, tokenistic outcomes or pacification are things we have to seriously pay attention to.

\section{Contributions to this issue}

In the first article of this special issue on environmental restorative justice, Miranda Forsyth and her colleagues, all based at the REGNET Institute at the Australian National University, take forward the legacy of the work of John and Valerie Braithwaite, and explore the role that restorative justice can play as part of the regulatory mix in the environmental area. In addition, they launch an open 'dialogue and debate about what an agenda for environmental restorative justice may take, in order to maximise its impact'. The tasks Forsyth and colleagues set themselves in drawing the contours of that agenda are: first, understanding the existing shape of the environmental regulatory landscape, to ensure that environmental restorative justice is not viewed as a noisy interloper, but rather as a valued fresh approach that respects, and builds upon, the histories of success and failure experienced in the field; second, making environmental restorative justice legible and accessible as philosophy, practice and principles; and third, acknowledging 'that environmental regulation raises specific conceptual challenges that are not present, or that manifest differently, in other domains where restorative justice has been used'.

Next, establishing conceptual alignments with the fields of green criminology and green victimology, Gema Varona decides to write about 'green restorative justice' rather than 'environmental restorative justice'. She defines green restorative justice 'as a restorative justice focused on environmental harm', whereby she understands harm as a concept that can encapsulate both criminalised and non-criminalised and individual and collective behaviours and activities. The framework Varona proposes embraces harms on ecosystems, human and non-human beings. Besides establishing these vital alignments, Varona investigates the challenges posed to the development of green restorative 
justice by the cultural and social movement of transhumanism. This movement, which fosters fantasies of unlimited technological progress, impedes social and moral accountability in relation to environmental harms. Transhumanist ideas have to be challenged, argues Varona, since 'cultural values are a precondition for the practice of restorative justice about ecosystemic harms and harms to animals'. Varona is thinking about the role of green restorative justice in terms of restoring limits - limits to hubris, to desmesura, to domination. But more than that, she thinks of the role of green restorative justice also in terms of restoring responseability, so profoundly endangered by different demobilising trends such as catastrophism, ecological techno-utopism and extreme-right integral ecologies.

Political scientist Angèle Minguet explores the role and place of restorative justice within worldwide environmental justice movements and their attempts to transform environmental conflicts. Based on the analysis of thousands of environmental conflicts collected by the Environmental Justice Organizations, Liabilities and Trade (EJOLT) project, and more specifically on two emblematic environmental conflict cases, in Nigeria and in Ecuador, she argues that it is essentially due to the inherent characteristics of environmental conflicts, and due to the fact that they almost never find a satisfying resolution through traditional criminal justice, that environmental justice movements ask for a restorative approach, and that restorative justice is a sine qua non condition to truly repair environmental injustices. Along with the necessity to identify all the actors who have caused the harm and to listen to multiple victims' stories and the meaning they give to these stories, Minguet identifies as one of the biggest challenges for restorative justice the necessity to engage businesses and public administrations voluntarily in a reparation process and thus make them acknowledge their responsibility.

Mark Hamilton's article explores the use of restorative justice conferencing in an environmental offending context in New Zealand and the use of restorative justice conferencing by the Land and Environment Court of New South Wales, Australia in the Aboriginal cultural offending context, highlighting the differences and similarities in jurisprudence while making suggestions for the future. Despite the significant presence of indigenous peoples in both Australia (Aborigines) and New Zealand (Māori) and their strong connection to the environment, New Zealand's legislations and policies seem to take a broader view of the environment which includes its physical aspects but also the social, economic, aesthetic and cultural connections embedded within that environment. In comparison, Australia's definition is relatively limited and focusses mostly on the physical components of the environment such as land, air and water, organic and inorganic matter and any living organism, also including human-made or modified structures and areas, while excluding the human utility in the environment or the culture embedded in the environment.

Inspired by the New Zealand and Australian experiences, Carlos Frederico Da Silva has analysed the different legal discourses arising from the collapse of the mining tailings dam in the city of Brumadinho (Brazil) in 2019. Whereas in the civil lawsuit context, legal professionals (judges, lawyers, prosecutors) acknowledged the damage to the ecosystem and the people who live in areas close 
to the collapse site, foregrounding the centrality of the victims' interests and the urgency of the need for environmental reparation, in the criminal procedure, similar institutional actors were not able to produce agreed responses to the same problematic situation due to their focus on retribution and competition of argumentation. The author contends that we need innovations in jurisprudence and legal cultures based on a new type of penal rationality where we integrate restoratively oriented transdisciplinary concepts and principles which may guide the legal decision-making process towards environmental restorative justice responses.

Next, Orika Komatsubara sets herself the task of imagining a community that includes non-human beings, by exploring the 1990s Moyainaoshi Movement in Minamata (Japan) which was created by the local government, groups of victims, victims' supporters and unaffected Minamata citizens, aiming to rebuild the community after severe and long-term pollution and contamination caused by the Chisso Co. Ltd factory in the early 1950s. Despite the extensive legal actions, compensation and area restoration undertaken throughout the years, it was the need for the restoration of a fractured community itself that was articulated by the movement. Komatsubara delves into the depths of the movement to find restorative justice traces, but also to nourish our imagination as to what the ethics of this movement could mean for environmental restorative justice in other contexts and for imagining an interspecies and intergenerational community.

Besides these rich and varied analyses and accounts, it is imperative to move the engagement in the field forward by undertaking small-scale pilot projects where experience can be slowly built until it turns into robust knowledge and expertise. In Notes from the Field, such pioneering initiatives and experiences are presented. Annette Hübschle, Ashleigh Dore and Harriet Davis-Mostert introduce an exciting pilot project that seeks to apply restorative justice principles to wildlife crime offences in South Africa and share lessons learnt for future initiatives and projects. Jordi Recordà Cos describes a small-scale pilot project in France which was initiated with the aim to protect the environment and address conflicts within local communities affected by disseminated pesticide pollution. English mediator Lawrence Kershen, who was involved in the mock ecocide trial organised by Polly Higgins, presents his reflections based on the 'Action for Bhopal' movement and restorative processes from within Extinction Rebellion. Environmental artist and activist Maria Lucia Cruz Correia narrates her experience with developing a restorative court for ecocide through artistic interventions, resulting in a proposal of the caring function of 'guardian of nature'.

For the Conversation series, Albert Dzur talks to world-renowned criminologist Rob White, whose work on green criminology, indigenous justice and what he calls 'reparative justice' in the environmental area is extremely important (White, 2013, 2014, 2017). The conversation highlights the personal and professional journey of White, also showing his critical look at the process of institutionalisation of environmental restorative justice. Nevertheless, the use of the term 'reparative justice' for this approach would not be completely 
uncontroversial and there are other scholars, such as Margaret Urban Walker (2006), who use the term 'reparative justice' rather differently, for example to challenge the focus on material aspects and to focus on the relational repair. Finally, the Book Review section presents a review by Tanya Jones of the recent book by Ben Almassi, Reparative environmental justice in a world of wounds (2020), whose work is based upon Walker's concept.

\section{A collective agenda in the making}

Despite the variety of terminology and accents - 'green restorative justice' (Varona, this issue), 'restorative environmental justice' (Minguet, this issue), 'reparative environmental justice' (Almassi, 2020) or 'environmental restorative justice' (Forsyth et al., this issue; Stark, 2016) - what we have called 'environmental restorative justice' refers essentially both to the ways in which restorative justice can be used in the context of environmental harms, crimes and conflicts and to the ways in which an environmental agenda can contribute to the evolving field of restorative justice (Forsyth et al., this issue). This agenda, while focusing on environmental issues, originates essentially from within the restorative justice movement, and is an agenda still to be fully delineated and defined.

Besides emphasising the knowledge and skills that we can bring to the table, we find it important to consider, not in the sense of discouragement, but in the sense of a critical and humble awareness, the knowledge and skills that we actually lack, and the challenges that lie ahead. At the conceptual level, it is clear that in order to make restorative justice applicable or relevant for addressing issues of environmental harms, crimes and conflicts, we must adopt another mindset which requires a move from the micro-level to the macro-level when looking at causes, consequences and responses. We have to rethink our notions of 'crime', 'offenders', 'victims', 'harm', 'community' and 'participation' as we have adopted them in restorative justice practices worldwide during last decades. Specific models will have to be developed and established in practice. In this regard, some of the key challenges and questions relate to how able restorative justice services are (or will be) to address long-term and complex environmental harms and conflicts that are often rooted in the historical past, socio-economic inequalities, global injustices and colonial history. How well prepared are restorative justice services to navigate the complexity and multilayered aspects of these cases which extend to sophisticated legal procedures and safeguards, manysided financial and compensation issues, multilevel collectivities and representational issues and power differences? How will we in restorative processes listen to the voice of nature and future generations? How will we decide what is the kind of expertise required to adequately speak for the other-thanhuman and who speaks with authenticity, credibility and legitimacy for nature? Important questions that arise in relation to the participation of corporate actors in restorative processes include: whom to focus on, how to assess harm and how to decide on degrees of accountability. How to identify the accountable 
stakeholder for restorative justice when causality is not established in court, or when the case cannot be dealt with anymore judicially because of legal prescription? Once a restorative option is given to corporations within a criminal justice process and they participate, how to make sure that their participation is genuine and voluntary? How to give corporations a human face? How to accommodate the participation of legal representatives? How to deal with regularly changing positions of senior managers? How to envision the role of spokespersons of the corporations? From whom can corporations take binding decisions, and who can write agreements and follow-up commitments? How to monitor non-compliance? Other challenges relate to the criteria by which decisions around restoration are to be made. How to disentangle material from non-material priorities? How to repair individual and collective harm whose impact might only be seen in the long term? And eventually, how to repair the irreparable?

As this special issue shows, these questions are challenging but can be answered through drawing and launching a common research and practice agenda where we not only share insights, ideas and experiences, but also learn from other disciplines which have a longer engagement with the topic. We need more test cases, at a different range of complexity, to describe and analyse daring, innovative restorative approaches and models empirically. In the context of environmental harms, crimes and conflicts, participatory processes can offer unique opportunities for citizens to explore and to challenge

the morality of commerce, or socioeconomic inequity, or the temptations of great wealth, or the responsibilities of the powerful, or what 'represents the law of the land', in a purposeful and meaningful way (Chiste, 2008: 99-100).

More generally, a framework, an agenda and a vision of environmental restorative justice must present a radically interdependent, global, intergenerational and interspecies alternative. This framework must be aligned to environmental justice movements, indigenous communities, civil society activists, creative judges and lawyers, regulators of our industries, environmental stewards, committed scientists and artists (see Forsyth et al., this issue). Despite our different motivations and epistemic positions, we can work in coalition to create and sustain spaces and practices of justice and repair.

\section{References}

Aertsen, I. (2006). The intermediate position of restorative justice: the case of Belgium. In

I. Aertsen, T. Daems \& L. Robert (eds.), Institutionalizing restorative justice (pp. 68-92). Cullompton: Willan Publishing.

Aertsen, I. (2008). Racak, Mahane Yehuda and Nyabyondo: restorative justice between the formal and the informal. In I. Aertsen, J. Arsovska, H.-C. Rohn, M. Valiñas \& K. Vanspauwen (eds.), Restoring justice after large-scale violent conflicts. Kosovo, DR Congo and the Israeli-Palestinian case (pp. 413-443). Cullompton: Willan Publishing. 
Aertsen, I. (2018). Restorative justice for victims of corporate violence. In G. Forti, C. Mazzucato, A. Visconti \& S. Giavazzi (eds.), Victims and corporations: legal challenges and empirical findings (pp. 235-258). Milano: Wolters Kluwer.

Al-Alosi, H. \& Hamilton, M. (2019). The ingredients of success for effective restorative justice conferencing in an environmental offending context. University of New South Wales Law Journal, 42(4), 1460-1488. doi: 10.2139/ssrn.3495322.

Almassi, B. (2020). Reparative environmental justice in a world of wounds. Lexington: Lexington Books.

Amy, D.J. (1983). The politics of environmental mediation. Ecology Law Quarterly, 11(1), 1-19.

Besthorn, F. (2004). Restorative justice in environmental restoration - the twin pillars of a just global environmental policy: hearing the voice of the victim. Journal of Societal and Social Policy, 3(1), 33-48.

Besthorn, F. (2012). Speaking earth: environmental restoration and restorative justice. In K. Wormer \& L. Walker (eds.), Restorative justice today: practical applications (pp. 233-244). Los Angeles: Sage.

Boyd, C.C. (2008). Expanding the arsenal for sentencing environmental crimes: would therapeutic jurisprudence and restorative justice work? William \& Mary Environmental Law and Policy Review, 32(2), 483-512.

Braithwaite, J. (2002). Restorative justice and responsive regulation. Oxford: Oxford University Press.

Braithwaite, J., Forsyth, M. \& Cleland, D. (2019). Restorative environmental justice: an introduction. In E. Biffi \& B. Pali (eds.), Environmental justice: restoring the future (pp. 13-17). Leuven: European Forum for Restorative Justice.

Chiste, K.B. (2008). Retribution, restoration and white-collar crime. The Dalhousie Law Journal, 31(1), 85-121.

Clapshaw, D. (2009). Restorative justice in resource management prosecutions - a facilitator's perspective. Retrieved from www.deborahclapshaw.co.nz (last accessed 28 November 2020).

Fowler, C. (2016). Environmental prosecution and restorative justice. Christchurch: Adderley Head.

Gabbay, Z.D. (2007). Exploring the limits of the restorative justice paradigm: restorative justice and white-collar crime. Cardozo Journal of Conflict Resolution, 8, 421-485.

Haraway, D. (2016). Staying with the trouble: making Kin in the Chthulucene. Durham: Duke University Press.

Higgins, P. (2010). Eradicating ecocide. London: Shepheard Walwyn Publishers.

Higgins, P. (2017). Changing the ground rules. Interviewed by Huw Spanner. High Profiles. Retrieved from https://highprofiles.info/interview/polly-higgins/ (last accessed 28 November 2020).

Jenkins, B. (2018). Environmental restorative justice: Canterbury cases. Conference Proceedings. International Association of Impact Assessment. Retrieved from https:// conferences.iaia.org/2018/final-papers/Jenkins,\%20Bryan\%20-\%20Environmental \%20Restorative\%20Justice.pdf (last accessed 20 January 2021).

Kershen, L. (2019). Implementing restorative justice to environmental harm. In E. Biffi \& B. Pali (eds.), Environmental justice: restoring the future (pp. 40-53). Leuven: European Forum for Restorative Justice.

Langer, A. (1994). We will only attain ecological conversion when it becomes socially desirable. Speech held at the Talks from Toblach/Dobbiaco, 10 September 1994, Time is ripe for a democratic ecological constitution. Retrieved from www.alexanderlanger.org/en/ 279/1355 (last accessed 28 November 2020). 
Llewellyn, J. \& Morrison, B. (2018). Deepening the relational ecology of restorative justice. The International Journal of Restorative Justice, 1(3), 343-355. doi: 10.5553/IJRJ/ 258908912018001003001.

Löschnig-Gespandl, M. (2003). Corporations, crime and restorative justice. In E.G.M. Weitekamp \& H.-J. Kerner (eds.), Restorative justice in context: international practice and directions (pp. 145-160). Cullompton: Willan Publishing.

Luedtke, A. (2014). Progression in the age of recession: restorative justice and white-collar crime in post-recession America. Brooklyn Journal of Corporate, Financial \& Commercial Law, 9(1), 311-344.

Lynch, M.J., Long, M.A. \& Stretesky, P.B. (2019). Green criminology and green theories of justice. Cham: Palgrave Macmillan.

McElrea, F. (2016). The use of restorative justice in RMA prosecutions. Resource Management Journal, 3(XII), 1-15.

Pain, N., Pepper, R., McCreath, M. \& Zorzetto, J. (2016). Restorative justice for environmental crime: an antipodean experience. Conference paper. International Union for Conservation of Nature Academy of Environmental Law Colloquium, Oslo Norway.

Pali, B. (2019). Restorative responses to environmental harms? Yes, we must! In E. Biffi \& B. Pali (eds.), Environmental justice: restoring the future (pp. 8-12). Leuven: European Forum for Restorative Justice.

Podziba, S. (2018). Mediating conflicts over sacred land. Conflict Resolution Quarterly, 35(4), 383-391. doi: 10.1002/crq.21217.

Preston, B. (2011). The use of restorative justice for environmental crime. Criminal Law Journal, 35(3), 136-153.

Rivers, L. (2012). Shareholder return: a Nuremberg defence? Ecocide and restorative justice. Environmental Law \& Management, 24(1), 17-19.

Stark, A. (2016). Environmental restorative justice. Pepperdine Dispute Resolution Journal, 16(3), 435-462.

Sugrue, V. (2015). What happens when values are put to work? A reflection in one outcome from a restorative justice conference in the criminal division of the District Court: environment warranted judge jurisdiction. Resource Management Journal , 19-22.

Umbreit, M., Geske, J. \& Lewis, T. (2015). Restorative justice impact on multinational corporations? A response to Andrew Brady Spalding's article. Ohio State Law Journal, $76,41-49$.

Walgrave, L. (2008). Restorative justice, self-interest and responsible citizenship. Cullompton: Willan Publishing.

Walker, M.U. (2006). Restorative justice and reparations. Journal of Social Philosophy, 37(3), 377-395. doi: 10.1111/j.1467-9833.2006.00343.x.

Walters, R. \& Westerhuis, D.S. (2013). Green crime and the role of environmental courts. Crime, Law and Social Change, 59, 279-290. doi: 10.1007/s10611-013-9415-4.

White, R. (2013). Environmental crime and problem-solving courts. Crime, Law and Social Change, 59(3), 267-278. doi: 10.1007/s10611-013-9414-5.

White, R. (2014). Indigenous communities, environmental protection and restorative justice. Australian Indigenous Law Review, 18(2), 43-54.

White, R. (2017). Reparative justice, environmental crime and penalties for the powerful. Crime, Law and Social Change, 67(2), 117-132. doi: 10.1007/s10611-016-9635-5.

Wijdekop, F. (2019a). Restorative justice responses to environmental harm. Retrieved from www.restorativejustice.nl/user/file/rapportiucnnl.pdf (last accessed 28 November 2020). 
Wijdekop, F. (2019b). Interview with Dominic Barter. In E. Biffi \& B. Pali (eds.), Environmental justice: restoring the future (pp. 54-60). Leuven: European Forum for Restorative Justice.

Wilson, C. (2016). Proactive restorative justice: a set of principles for enhancing public participation. Environmental and Planning Law Journal, 33(3), 252-263.

Wright, M. (2019). Restorative justice with corporations: the idea and the practicality. In B. Pali, K. Lauwaert \& S. Pleysier (eds.), The praxis of justice (pp. 281-292). The Hague: Eleven International Publishing. 